\title{
Effects of antimicrobial exposure on detrital biofilm metabolism in urban and rural stream environments
}

\author{
Rikke Jepsen $^{\mathrm{a}}$, Ke He ${ }^{\mathrm{b}}$, Lee Blaney ${ }^{\mathrm{b}}$, Christopher Swan ${ }^{\mathrm{a}, *}$ \\ a Department of Geography and Environmental Systems, University of Maryland, Baltimore County, 1000 Hilltop Circle, Baltimore, MD 21250, USA \\ ${ }^{b}$ University of Maryland, Department of Chemical, Biochemical, and Environmental Engineering, Baltimore County, 1000 Hilltop Circle, Engineering 314, Baltimore, MD 21250, USA
}

\section{H I G H L I G H T S}

- There is limited knowledge about how antimicrobials affect stream carbon processing.

- Antimicrobial exposure did not significantly impact leaf biofilm carbon processing.

- Urban leaf biofilms were less impacted by antimicrobials than rural biofilms.

- Leaf mixtures did not buffer antimicrobial effects compared to single species leaves.

- Antimicrobial pollution can lead to complex outcomes for carbon processing in rivers.

\section{A R T I C L E I N F O}

\section{Article history:}

Received 4 October 2018

Received in revised form 13 February 2019

Accepted 16 February 2019

Available online 21 February 2019

Editor: Sergi Sabater

\section{Keywords:}

Antibiotic

Carbon processing

Ciprofloxacin

Climbazole

Leaf litter breakdown

Streams

\section{G R A P H I C A L A B S T R A C T}

Biological Oxygen Demand by Non-urban vs Urban Microbial Communities under Stress from Personal Care Products
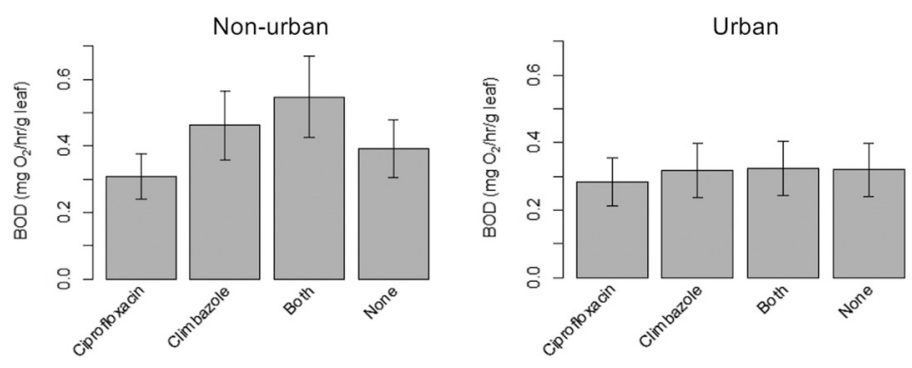

\begin{abstract}
A B S T R A C T
The occurrence of antimicrobials and other pharmaceuticals in streams is increasingly being reported, yet the impacts of these contaminants of emerging concern on aquatic ecosystems are relatively unknown. Bacteria and fungi are vital components of stream environments and, therefore, exposure to antimicrobials may have important consequences for ecosystem services, such as carbon cycling. The objective of this study was to investigate how two antimicrobials, ciprofloxacin and climbazole, impact detrital biofilm metabolism in urban and rural streams. To establish baseline conditions, the biological oxygen demand (BOD) of red maple (Acer rubrum) biofilms was measured in one urban and one rural stream. In mesocosm studies, the BOD of biofilms on singleand mixed-species leaf litter from the same sites was measured after exposure to $10 \mu \mathrm{g} / \mathrm{L}$ of the antimicrobials, both in combination and individually. The presence of ciprofloxacin and climbazole did not affect BOD compared to the controls at the urban site, although significant differences were identified for select treatments at the rural site. In addition, the BOD of mixed-leaf biofilms was not significantly different from that of single species litter after exposure. Overall, exposure to $10 \mu \mathrm{g} / \mathrm{L}$ of the antimicrobials did not significantly impact community-level carbon processing by the leaf biofilms, and leaf mixtures did not result in increased biofilm BOD compared to single species leaves. The outcomes of this work demonstrate a need for further research for the understanding the effects of antimicrobials on rural streams to prevent unintended consequences to ecological processes and biota from future development, leaking septic systems, and wastewater spills.
\end{abstract}

@ 2019 Published by Elsevier B.V.

\footnotetext{
* Corresponding author.

E-mail address: Chris.Swan@umbc.edu (C. Swan).
}

\section{Introduction}

Human- and animal-use antimicrobials routinely enter freshwater streams, where these contaminants have the potential to interfere 
with non-target aquatic organisms (Daughton and Ternes, 1999). While commonly-used drugs have been screened to determine their toxicity to various aquatic organisms (Kümmerer, 2003; Brausch and Rand, 2011; Rosi-Marshall et al., 2013 and references therein), relatively little information is available on the effects of these drugs on the structure and function of aquatic ecosystems. Unlike seasonal pollutants, such as pesticides or road salts, antimicrobial compounds can be continuously released to freshwater environments in rural, urban, and suburban areas (Rosi-Marshall and Royer, 2012). The extended temporal release of these contaminants across stream networks leads to sub-lethal, but chronic, exposures that are known as pseudo-persistence (RosiMarshall and Royer, 2012; Ebele et al., 2017). In addition, streams receive a combination of antimicrobials with different modes of action, complicating efforts to not only deconvolute the effects of individual drugs, but also predict the effects of mixtures due to complex drug-drug interactions (Cleuvers, 2004; Lawrence et al., 2012). This study was designed to identify the impacts of two widely-used antimicrobials on in-stream carbon processing in an urban stream regularly exposed to contaminants (Rosi et al., 2018) and a rural stream located in a state park.

Antimicrobials enter aquatic ecosystems in a variety of ways. Wastewater treatment plants (WWTPs) are considered the primary source due to direct discharge of treated wastewater effluent containing biologically active compounds, including antimicrobials and other pharmaceuticals, into streams and rivers (Daughton and Ternes, 1999; He et al., 2015). Leaking wastewater collection systems may also contribute to antimicrobial pollution. In fact, $23 \%$ of United States sewage pipes were in poor condition in 2000 , with a predicted increase to $45 \%$ by 2020 (United States Environmental Protection Agency, 2002), resulting in the discharge of over 3.4 trillion liters of raw wastewater into streams each year (American Society of Civil Engineers, 2013). Other sources of antimicrobials include hospital waste, manufacturing plant discharges, improper disposal of drugs, and land application of manure or wastewater-based biosolids as soil amendments (Monteiro and Boxall, 2010). To date, over 200 pharmaceutical compounds, including antimicrobials, have been identified in streams around the world (Petrie et al., 2015), as well as in streams local to our field work (e.g., Rosi et al., 2018). The antimicrobials examined in this study were ciprofloxacin and climbazole. These compounds were chosen due to their frequent detection in streams (Andreozzi et al., 2003; Chen and Ying, 2015; He et al., 2015). Ciprofloxacin is a fluoroquinolone antibiotic that targets Gram-positive and -negative bacteria by inhibiting DNA gyrase and topoisomerase IV, enzymes important to DNA replication (Robinson et al., 2005). Climbazole targets fungi by hindering production of C14demethylase to impede biosynthesis of ergosterol, an important plasma membrane component (Richter et al., 2013).

Aquatic microorganisms, such as bacteria and fungi, are susceptible to antimicrobial exposure. Rosi-Marshall et al. (2013) reported that biofilm respiration was reduced by up to $91 \%$ when microbial biofilms were exposed to an antibiotic (ciprofloxacin), antihistamine (diphenhydramine), and antidiabetic (metformin). Recent evidence also suggests that antimicrobial pollution can result in the development and propagation of antibiotic-resistant bacteria and alter microbial activity (Yergeau et al., 2012). Anthropogenic contamination of streams also decreased the biomass of decomposers and biofilms (Rosi-Marshall and Kelly, 2015) and changed macroinvertebrate assemblages (Dussault et al., 2008; Brausch and Rand, 2011). These impacts to stream microbes are important to study because they make significant contributions to organic matter processing in aquatic ecosystems (Allan and Castillo, 2007; Feckler et al., 2015). The breakdown of organic matter in streams is initiated through microbial colonization and conditioning of detritus via formation of biofilms, which are complex matrices that contain nutrients, bacteria, fungi, algae, viruses, and protozoa (Besemer, 2015). This organic matter processing pathway forms the basis of detrital food webs by releasing bound nutrients and reducing the amount of decaying material the stream (Peters et al., 2013). To better understand how antimicrobials impact stream biofilms and their role in carbon processing, this study exposed biofilms to various treatments of the antimicrobials, ciprofloxacin and climbazole, and measured the associated microbial oxygen demand.

No previous studies have addressed whether effects of antimicrobials vary between single- and mixed-species leaf litter. The species composition of riparian forest communities is critical because the leaves contribute to organic matter into streams, especially in small headwater tributaries where the bulk of allochthonous detritus is autumn-shed leaves (Petersen and Cummins, 1974; Ostrofsky, 1993). Leaf species vary in composition, including nutrient content (e.g., carbon-nitrogen ratios), structural components (e.g., lignin, cellulose), and secondary compounds (e.g., tannins, waxes) (Webster and Benfield, 1986; Gessner et al., 1999). Microorganisms tend to be deterred by phenolic compounds (Stoler and Relyea, 2011) and recalcitrant structural components (Gessner et al., 1999). However, a high nitrogen content and a small proportion of resilient polymers improve the biodegradability of leaf material (Melillo et al., 1982; Swan and Palmer, 2004).

Litter that includes labile, recalcitrant, and intermediate leaf species usually hosts a greater diversity of microbes compared to single species litter (Bärlocher and Graça, 2002; Newman et al., 2015). In mixtures, labile leaves are colonized and processed quickly, while refractory leaves serve as a long-term energy source. Leaf mixtures, therefore, provide stream biota with a more stable supply of nutrients compared to single-source litter that is degraded at roughly the same rate (Swan and Palmer, 2006). The more diverse biofilms in leaf mixtures are expected to be more resistant to negative effects associated with antimicrobial exposures due to functional trait redundancy. In this study, biological (or biochemical) oxygen demand (BOD) was used to assess the activity of the biofilm communities after exposure to ciprofloxacin and climbazole. BOD is a measure of how much oxygen aerobic microorganisms remove from water to decompose organic material (e.g., the mineralization of organic $\mathrm{C}$ to $\mathrm{CO}_{2}$ ) (Parkin et al., 1996; Hach et al., 1997). A high BOD is indicative of more metabolically-active microorganisms (Erickson et al., 2013; Hwang et al., 2016).

The objective of this study was to investigate the effects of two antimicrobial agents, ciprofloxacin and climbazole, on leaf-associated biofilms from an urban and a rural stream. BOD was used as a measure of microbial activity. The following questions guided the experiment: (1) what is the BOD of biofilms sampled in an urban stream compared to a rural stream?; (2) how does exposure to a combination of an antibacterial (ciprofloxacin) and a fungicide (climbazole) impact BOD of leaf biofilms compared to single-drug exposures?; and (3) do mixtures of leaf species buffer the impacts of antimicrobial exposure on microbial respiration compared to homogenous, single species leaf litter? Outcomes from this study should indicate that additional research into elucidating the consequences of antimicrobial exposure in rural stream ecosystems is necessary.

\section{Materials and methods}

\subsection{Study sites, site environmental conditions, and pharmaceuticals used in} study

Stream water was collected at one rural and one urban site. The rural site was a spring-fed, first-order stream in Patapsco Valley State Park, Baltimore County, Maryland (MD) $\left(39^{\circ} 14^{\prime} 44.5^{\prime \prime} \mathrm{N}, 76^{\circ} 45^{\prime} 15.1^{\prime \prime} \mathrm{W}\right.$; Fig. 1A). Crayfish, salamanders, stonefly nymphs, and mayfly nymphs were observed at this location. The urban site was a fifth-order (Brinckerhoff, 2013) urbanized section of the Gwynns Falls river, accessed at Lower Gwynns Falls Park, Baltimore, MD (39 $16^{\prime} 43.5^{\prime \prime}$ $\mathrm{N}, 76^{\circ} 39^{\prime} 40.5^{\prime \prime} \mathrm{W}$; Fig. 1B). Most aquatic organisms found at this site were non-biting midge larvae and pouch snails. The temperature, dissolved oxygen (DO), conductivity, total nitrogen (TN), total organic carbon (TOC), orthophosphate $(\mathrm{P})$, and $\mathrm{pH}$ were measured for water from the study sites during the May to August 2017 study period (Table 1). To determine the TN and TOC, a $40-\mathrm{mL}$ sample of filtered 

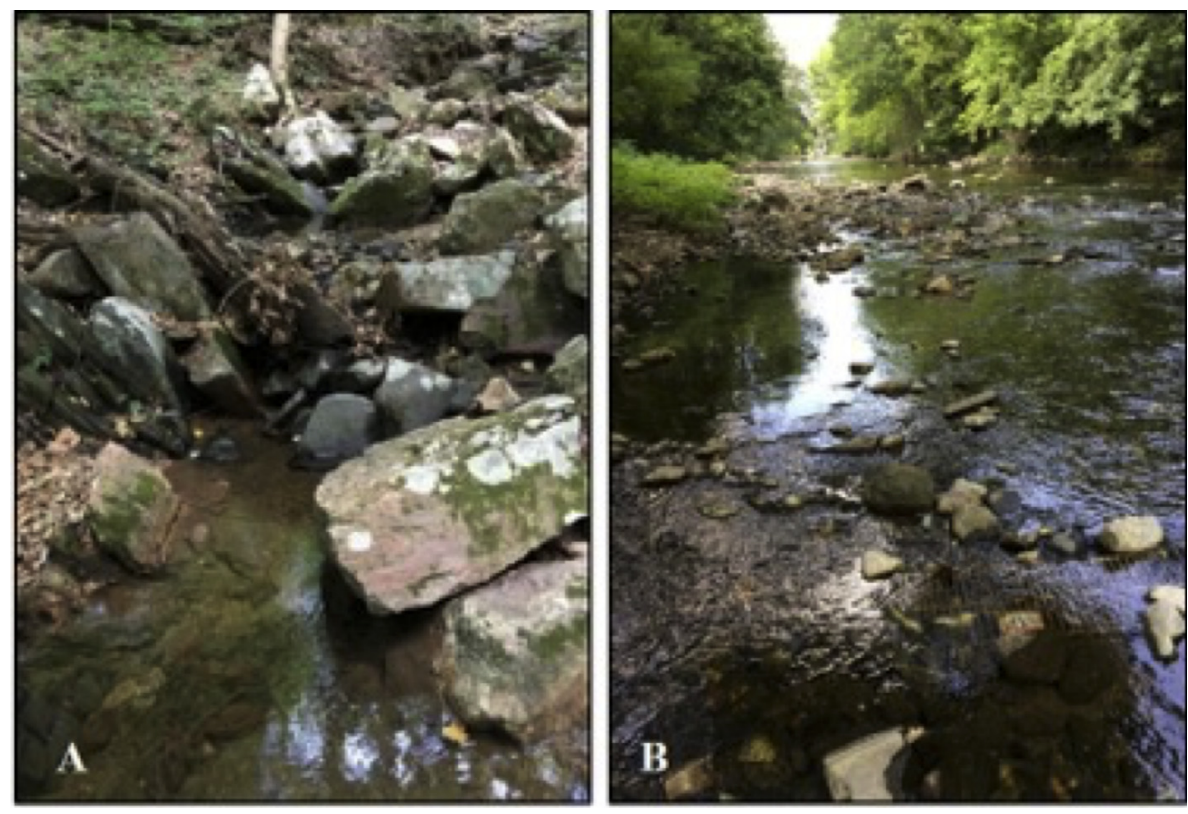

Fig. 1. (A) Patapsco tributary and (B) Gwynns Falls site.

stream water from each site was analyzed with a Shimadzu TOC-L Analyzer (Shimadzu Corporation; Columbia, MD). Temperature, DO, and conductivity were measured using probes placed in the stream water (YSI; Yellow Springs, OH). P(V) and pH were determined using LaMotte SMART3 Colorimeter test kits (LaMotte; Chestertown, MD).

Ciprofloxacin ( $>98 \%$ purity) and climbazole ( $>98 \%$ purity) were supplied by TCI America (Portland, OR). A $1 \mathrm{~g} / \mathrm{L}$ stock solution was prepared for both antimicrobials by dissolving $100 \mathrm{mg}$ in $100 \mathrm{~mL}$ of deionized (DI) water with $3 \mathrm{mM}$ hydrochloric acid $(\mathrm{HCl})$. Then, $500 \mu \mathrm{L}$ of the stock solution was added to $499.5 \mathrm{~mL}$ of DI water to make a $1 \mathrm{mg} / \mathrm{L}$ working solution. Working solutions were added directly to microcosm, in which the antimicrobials were diluted to $10 \mu \mathrm{g} / \mathrm{L}$ by adding recently collected (i.e., within one day) filtered stream water from the sites.

\subsection{Biological oxygen demand at study sites}

Newly senesced red maple (Acer rubrum) leaves were collected from the University of Maryland, Baltimore County campus in Fall 2016. Leaves were rotated frequently to promote air drying, then stored in paper bags at room temperature until Summer 2017. At that time, twenty coarse-mesh litter bags $(23 \times 10 \mathrm{~cm}, 7 \times 11 \mathrm{~mm}$ mesh; Swan and Palmer, 2004) were filled with ten similarly-sized red maple leaves. Ten-litter bags were deployed at each site, maintained in a fullysubmerged state, and conditioned for three weeks when microbial colonization is predicted to be at high levels (see Swan and Palmer, 2004 and references therein).

After 3 weeks the bags were removed, placed in individual zip-top bags, and transported to the lab on ice. At the same time, $7.5 \mathrm{~L}$ of stream

Table 1

Average environmental conditions at the study sites from May to August 2017; $n=5$.

\begin{tabular}{lcc}
\hline Water quality parameter & Patapsco $(\min , \max )$ & Gwynns Falls $(\min , \max )$ \\
\hline Temperature $\left({ }^{\circ} \mathrm{C}\right)$ & $19.10(17.5,20.4)$ & $22.88(21.1,24.5)$ \\
DO $(\mathrm{mg} / \mathrm{L})$ & $8.47(7.69,9.08)$ & $9.95(9.07,11.42)$ \\
Conductivity $(\mu \mathrm{S} / \mathrm{cm})$ & $181(151,205)$ & $430(375,473)$ \\
$\mathrm{TN}(\mathrm{mg} / \mathrm{L})$ & $0.82(0.56,0.97)$ & $1.37(1.15,1.60)$ \\
$\mathrm{TOC}(\mathrm{mg} / \mathrm{L})$ & $3.41(3.05,3.72)$ & $4.38(3.96,4.95)$ \\
$\mathrm{P}(\mathrm{mg} / \mathrm{L})$ & $0.27(0.26,0.29)$ & $0.36(0.04,0.94)$ \\
$\mathrm{pH}$ & $7.58(7.50,7.69)$ & $8.29(8.12,8.69)$ \\
\hline
\end{tabular}

water were collected from each site and filtered through a $63-\mu \mathrm{m}$ sieve. Using a cork borer, six $2.2-\mathrm{cm}$ diameter cores were cut from the red maple leaves in each litter bag. Each group of six cores was placed in a labeled BOD bottle, with approximately $300 \mathrm{~mL}$ of filtered stream water from the corresponding site. An additional BOD bottle, containing no leaf material and $300 \mathrm{~mL}$ of filtered stream water was prepared for each site as a negative control. Three 3.2-mm stainless steel ball bearings were placed in each BOD bottle to mix the water and prevent a boundary layer that could inhibit oxygen diffusion to the leaf surface. The full BOD bottles were sealed with a glass stopper and checked to ensure the absence of air bubbles. The bottles were placed in a dark, $21^{\circ} \mathrm{C}$, to match ambient water temperatures, environment on a shaker table set to $25 \%$ maximum speed (125 rpm) to provide gentle mixing and movement of the ball bearing, but not enough to damage the leaves. After $3 \mathrm{~h}$, the DO concentration was measured in each bottle using a YSI MultiLab 4010-3 interface with a YSI IDS ProOBOD probe (YSI; Yellow Springs, $\mathrm{OH})$. Leaf cores were removed and placed in aluminum trays to dry at $21^{\circ} \mathrm{C}$ for 4 days. When completely dry, the cores were weighed, and the biofilm BOD was calculated using Eq. (1). When observed, lower BOD values than the blank controls were attributed to inhibitory impacts of the antimicrobials on biofilm processes.

$\operatorname{BOD}\left(\frac{\mathrm{mg}}{\mathrm{hrg}}\right)=\frac{\left(\mathrm{O}_{2} \text { in blank }\left(\frac{\mathrm{mg}}{\mathrm{L}}\right)-\mathrm{O}_{2} \text { in sample }\left(\frac{\mathrm{mg}}{\mathrm{L}}\right)\right) \times \text { Volume of bottle }(\mathrm{L})}{\text { Incubation time }(\mathrm{hr}) \times \text { Mass of dry leaf cores }(\mathrm{g})}$

\subsection{Antimicrobial exposure microcosm study}

Newly senesced leaves from tulip poplar (Liriodendron tulipifera), red maple, and American beech (Fagus grandifolia) were collected from forested areas in Howard, Baltimore, and Carroll Counties, MD in Fall 2016. The collected leaves were air-dried and stored in paper bags at room temperature. For each site, litter bags were constructed as follows: (i) four replicates with three tulip poplar leaves; (ii) four replicates with five red maple leaves; (iii) four replicates with five beech leaves; and, (iv) four replicates with a mixture of two tulip poplar, four red maple, and four beech leaves. Fewer tulip poplar leaves were used in the litter bags due to their larger size, which enabled more cores to be cut from an individual leaf. Litter bags were attached to 
Table 2

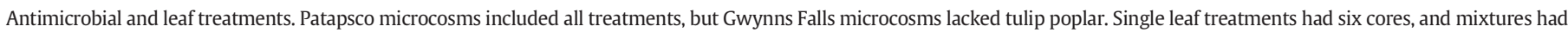
an equal contribution of species totaling six cores per microcosm. Concentrations of ciprofloxacin and climbazole were nominal at $10 \mu \mathrm{g} / \mathrm{L}$.

\begin{tabular}{|c|c|c|c|c|}
\hline Antimicrobial treatment & & Leaf & Treatment & \\
\hline Ciprofloxacin & Tulip poplar & Red maple & American beech & Tulip poplar, red maple, American beech \\
\hline Climbazole & Tulip poplar & Red maple & American beech & Tulip poplar, red maple, American beech \\
\hline Ciprofloxacin and climbazole & Tulip poplar & Red maple & American beech & Tulip poplar, red maple, American beech \\
\hline No drug & Tulip poplar & Red maple & American beech & Tulip poplar, red maple, American beech \\
\hline No drug & - & - & - & - \\
\hline
\end{tabular}

wire loops, submerged at the Patapsco and Gwynns Falls sites for 2 weeks for microbial conditioning, retrieved, placed in individual ziptop bags, and transported to the lab. Unfortunately, tulip poplar leaves were not recovered from Gwynns Falls because the stream displaced the fragile, decaying leaf material from the litter bags. During litter bag retrieval, $15 \mathrm{~L}$ of stream water was collected at each site and passed through a $63-\mu \mathrm{m}$ sieve. Five replicate experiments were completed for each site; however, the fourth Gwynns Falls replicate was lost to a storm. In Summer 2017 when leaves are still present in local streams and antimicrobial agents are also present (Rosi et al., 2018), litter bags were deployed and retrieved as follows: June 5-19; June 19-July 3; July 3-17; July 17-31; and, July 31-August 14.

Forty 1-L glass mason jars served as microcosms. The jars were labeled with a unique ID, stream site, and the leaf/drug treatments, which are outlined in Table 2. Six 2.2-cm diameter cores were cut from each conditioned leaf species and placed in the appropriate microcosm. For single-drug treatments, $8 \mathrm{~mL}$ of the $1 \mathrm{mg} / \mathrm{L}$ antimicrobial working solution (see Section 2.4) was placed in the microcosm, followed by $792 \mathrm{~mL}$ of filtered stream water. Microcosms containing both ciprofloxacin and climbazole received $8 \mathrm{~mL}$ of each antimicrobial working solution and $784 \mathrm{~mL}$ of filtered stream water. These conditions resulted in nominal antimicrobial concentrations of $10 \mu \mathrm{g} / \mathrm{L}$ at the start of each experiment. A bubbler system was implemented by connecting air pumps to separator valves, which allowed for the placement of one section of clear aquarium tubing into each jar; the tube opening was located approximately one third of the way into the water.

The microcosms were kept in under ambient light conditions in the lab at $21{ }^{\circ} \mathrm{C}$ environment for 2 weeks. The antimicrobials were replenished every 3 days by replacing $8 \mathrm{~mL}$ of the microcosm liquid with $8 \mathrm{~mL}$ of the working solution to account for antimicrobial loss via sorption and degradation mechanisms. After 14 days, the biofilm BOD was determined using the protocols described in Section 2.2.

To confirm antimicrobial concentrations over the 14-day tests, 10$\mathrm{mL}$ samples from the third and fifth replicates were collected in amber glass bottles from each microcosm on days one and fourteen. Upon receiving the samples, $50-\mu \mathrm{L}$ of an internal standard solution, containing $100 \mu \mathrm{g} / \mathrm{L}$ of ciprofloxacin- $\mathrm{d}_{8}$ and climbazole- $\mathrm{d}_{4}$ (Toronto Research Chemicals; Toronto, CA) in methanol, was mixed with $950 \mu \mathrm{L}$ of sample water in amber vials. Antimicrobial concentrations were analyzed within 2 days to prevent analyte degradation. The average microcosm drug concentrations were close to, or at, the target concentration for both ciprofloxacin and climbazole on the first day of the study. Concentrations of each antimicrobial moderately increased during the two-

Table 3

Average antimicrobial concentrations $(\mu \mathrm{g} / \mathrm{L})$ in microcosms ( \pm standard error of the mean (SE)) on days one and fourteen for replicates three and five. Limits of detection are $0.3 \mu \mathrm{g} / \mathrm{L}$ for ciprofloxacin and $0.1 \mu \mathrm{g} / \mathrm{L}$ for climbazole.

\begin{tabular}{llllll}
\hline \multirow{2}{*}{ Treatment } & \multicolumn{2}{l}{ Ciprofloxacin } & & & \multicolumn{2}{l}{ Climbazole } & \\
\cline { 2 - 3 } & Day 1 & Day 14 & & Day 1 & Day 14 \\
\hline No antimicrobials & $<0.3$ & $<0.3$ & & $<0.1$ & $<0.1$ \\
Single antimicrobials & $10.0 \pm 0.2$ & $11.3 \pm 1.3$ & & $10.4 \pm 0.1$ & $16.2 \pm 2.2$ \\
Both antimicrobials & $10.3 \pm 0.2$ & $11.4 \pm 1.1$ & & $10.0 \pm 0.1$ & $18.6 \pm 2.4$
\end{tabular}

week study due to the competing influences of degradation processes and exogenous addition (Table 3 ).

\subsection{Analysis of ciprofloxacin and climbazole}

Stream water $(1 \mathrm{~L})$ was collected in methanol-rinsed amber bottles each time litter bags were deployed at the Patapsco and Gwynns Falls sites, transported to the lab on ice and passed through 1.2- $\mu \mathrm{m}$ glass fiber filters (Millipore Sigma; Burlington, MA). The solution $\mathrm{pH}$ was lowered to 2.5-3.0 using 3 M HCL. Solid-phase extraction (SPE) was performed using a modified protocol from He and Blaney (2015). Within $48 \mathrm{~h}$, samples were extracted onto hydrophilic-lipophilic balanced (HLB) cartridges $\left(150 \mathrm{mg}, 6 \mathrm{~cm}^{3}\right)$ using a 20-position extraction manifold (Waters Corporation; Milford, MA). Six 100-mL subsamples, comprising three replicates and three replicates spiked with $10 \mathrm{ng}$ of ciprofloxacin and climbazole, were used for determining analyte concentration and absolute recovery. The HLB cartridges were conditioned using $5 \mathrm{~mL}$ methanol and $5 \mathrm{~mL}$ acidified DI water $(\mathrm{pH} 3, \mathrm{HCl})$. The sample loading flow rate was maintained by vacuum at $4-8 \mathrm{~mL} \mathrm{~min}^{-1}$. Then, each cartridge was sequentially washed with $5 \mathrm{~mL}$ DI water and $2 \mathrm{~mL} 50 \%$ methanol, then the two antimicrobials eluted using $7 \mathrm{~mL}$ acetonitrile under gravity. In the dark, nitrogen gas was used to evaporate the acetonitrile-based extract to dryness at room temperature. The extract was reconstituted in $0.5 \mathrm{~mL}$ methanol, which contained $10 \mu \mathrm{g} / \mathrm{L}$ of the ciprofloxacin- $\mathrm{d}_{8}$ and climbazole- $d_{4}$ internal standards, diluted to $1 \mathrm{~mL}$ with DI water, kept at $-20{ }^{\circ} \mathrm{C}$ in amber vials, and analyzed within 1 week.

Ciprofloxacin, climbazole, and internal standards were analyzed using an UltiMate 3000 liquid chromatograph (LC) connected to a Thermo TSQ Quantum Access Max triple quadrupole tandem mass spectrometer (MS/MS) (Thermo; Waltham, MA). Here, 50- $\mu \mathrm{L}$ samples were injected onto a Waters Symmetry C18 column $(3 \times 150 \mathrm{~mm}, 3.5 \mu \mathrm{m})$ with a C18 guard column $(3 \times 10 \mathrm{~mm}, 3.0 \mu \mathrm{m})$. Analytes were eluted with a mobile phase that contained (i) LC-MS grade methanol with $0.1 \%$ formic acid and (ii) LC-MS-grade water with $0.1 \%$ formic acid ( $\mathrm{pH} 2.7$ ). The mobile phase flow rate was maintained at $300 \mu \mathrm{L} \mathrm{min}^{-1}$, and the gradient elution scheme is shown in Table 4. The antimicrobials and their deuterated internal standards were ionized using positive electrospray ionization (ESI) mode. The spray voltage was $3000 \mathrm{~V}$, the capillary temperature was $350{ }^{\circ} \mathrm{C}$, the vaporizer temperature was $300{ }^{\circ} \mathrm{C}$, the sheath gas pressure was 35 (arbitrary units, nitrogen), the auxiliary gas pressure was 10 (arbitrary units, nitrogen), and the collision-induced dissociation pressure was 1.5 mTorr (argon). For each analyte, the precursor ion and the two most abundant product ions were selected for quantitation and

Table 4

LC gradient elution scheme (\% of mobile phase).

\begin{tabular}{lcc}
\hline Time $(\mathrm{min})$ & Methanol $(0.1 \%$ formic acid $)$ & Water $(0.1 \%$ formic acid $)$ \\
\hline 0.0 & 20 & 80 \\
2.0 & 20 & 80 \\
3.5 & 80 & 20 \\
6.5 & 80 & 20 \\
8.0 & 20 & 80 \\
12.0 & 20 & 80
\end{tabular}


Table 5

Operational parameters and instrumental/method performance metrics for the LC-ESI-MS/MS method.

\begin{tabular}{|c|c|c|c|c|c|c|c|}
\hline Chemical $^{\mathrm{a}}$ & Ion transition ${ }^{\mathrm{b}}$ & $\mathrm{CE}(\mathrm{V})$ & TLO & $\begin{array}{l}\text { Linear range } \\
(\mu \mathrm{g} / \mathrm{L})^{\mathrm{c}}\end{array}$ & $\mathrm{R}^{2}$ & $\begin{array}{l}\mathrm{MDL}^{\mathrm{d}} \\
(\mathrm{ng} / \mathrm{L})\end{array}$ & $\begin{array}{l}\mathrm{MQL}^{\mathrm{e}} \\
(\mathrm{ng} / \mathrm{L})\end{array}$ \\
\hline Ciprofloxacin & $\begin{array}{l}\mathbf{3 3 2 . 2} \rightarrow \mathbf{3 1 4 . 1} \\
332.2 \rightarrow 288.1\end{array}$ & $\begin{array}{l}20 \\
16\end{array}$ & 75 & $1-25$ & 0.9983 & 3.0 & 10 \\
\hline Ciprofloxacin-d8 & $\begin{array}{l}\mathbf{3 4 0 . 1} \rightarrow \mathbf{3 2 2 . 1} \\
340.1 \rightarrow 296.1\end{array}$ & $\begin{array}{l}21 \\
16\end{array}$ & 82 & 5 & - & - & - \\
\hline Climbazole & $\begin{array}{l}\mathbf{2 9 3 . 1} \rightarrow \mathbf{2 2 5 . 0} \\
293.1 \rightarrow 197.1 \\
297.1 \rightarrow 201.1\end{array}$ & $\begin{array}{l}15 \\
16 \\
15\end{array}$ & 81 & $1-25$ & 0.9997 & 1.0 & 3.3 \\
\hline
\end{tabular}

Acronyms: CE, Collision Energy; TLO, Tube Lens Offset; MDL, Method Detection Limit; MQL, Method Quantitation Limit.

a Ciprofloxacin-d8 and climbazole-d4 were used as internal standards for ciprofloxacin and climbazole.

b The first transition (bold) was used for quantitation, and the second transition (italics) was used for confirmation.

c The concentration of internal standards was $5 \mu \mathrm{g} / \mathrm{L}$ in all samples.

d For the $100 \mathrm{~mL}$ stream water samples.

e $\mathrm{MQL}=\mathrm{MDL} \times 3.3$.

confirmation in selected reaction monitoring mode. The tube lens offset and collision energy were optimized for each analyte. See Table 5 for complete ESI-MS/MS parameters.

\subsection{Statistical analysis}

All statistical analyses were performed in R Studio (version 1.0.153). To address research question one, the significance of the difference between the mean BOD of the urban and rural detrital biofilms was compared using a two-sample $t$-test. Prior to the analysis, the normality and equal variances assumptions were checked using a normal quantile-quantile $(\mathrm{Q}-\mathrm{Q})$ plot and an F-test of equal variances, respectively. To address research question two and determine how exposure to both antimicrobials impacts biofilm BOD compared to single drug exposures, a three-way factorial analysis of variance (ANOVA) was implemented with the following factors: stream site; antimicrobial treatment; and leaf treatment. To account for the loss of tulip poplar leaves in the Gwynns Falls litter bags, separate two-way factorial ANOVAs were computed for each site by removing the site factor and retaining the antimicrobial and leaf treatment factors. Post hoc analyses were conducted on significant effects using Tukey's honest significant difference (HSD) method. To address research question three and determine if leaf mixtures buffer the effects of antimicrobials on biofilms compared to single species leaf litter, a one-way ANOVA was implemented. Before performing ANOVAs, the assumptions of normality and equal variance of the residuals were checked using a normal Q-Q plot and Levene's test, respectively. For all multi-way ANOVAs, the most complex, least significant term was removed from the analysis to obtain the least complex model. The probability of a Type I error was set to $\alpha=0.05$.

\section{Results and discussion}

\subsection{Antimicrobial occurrence at study sites}

Water samples from the Patapsco and Gwynns Falls sites were measured five times in Summer 2017 during retrieval of the conditioned leaf litter bags. At Gwynns Falls, ciprofloxacin and climbazole concentrations were below the limits of detection, $3 \mathrm{ng} / \mathrm{L}$ and $1 \mathrm{ng} / \mathrm{L}$, respectively. Ciprofloxacin was not detected at the Patapsco tributary site; however, $7.7 \pm 0.9 \mathrm{ng} / \mathrm{L}$ climbazole was measured in the sample collected on August 14, 2017. A potential source of climbazole at this site is leaking septic tanks from older residential areas bordering the park (Harrison et al., 2012), which have also been implicated as sources of wastewater indicator organisms (Chesapeake Bay Foundation, 2016). For example, in July 2016, Enterococcus spp. was measured at levels that were $304 \times$ greater than the recommended safety standards after $2.5 \mathrm{~cm}$ of precipitation, though no significant precipitation occurred on or near August 14. Furthermore, the conductivity of water from the Patapsco site was slightly elevated compared to the background conductivity (i.e., 145 to
$160 \mu \mathrm{S} / \mathrm{cm}$ ) of streams in Maryland's Piedmont region (Morgan et al., 2012). The conductivity of the Patapsco tributary ranged from 151 to $205 \mu \mathrm{S} / \mathrm{cm}$ with a mean value of $181 \mu \mathrm{S} / \mathrm{cm}$, and this slight elevation in conductivity can be an indicator of septic tank leakage (Hyer, 2006).

\subsection{Differences in biological oxygen demand between study sites}

The typical BOD of litter biofilms in North American streams, depending on the leaf species, ranges from 0.03 to $1.50 \mathrm{mg} \mathrm{O} / \mathrm{h} / \mathrm{g}$ leaf (Tank et al., 1993; Royer and Minshall, 2001; Gulis and Suberkropp, 2003; Stelzer et al., 2003; Mehring et al., 2010; Meter et al., 2012). BOD measurements from the Patapsco and Gwynns Falls sites were 0.10-1.22 $\mathrm{mg} \mathrm{O}_{2} / \mathrm{h} / \mathrm{g}$ leaf, with an average of $0.65 \mathrm{mg} \mathrm{O} / 2 / \mathrm{h} / \mathrm{g}$ leaf. Nevertheless, the BOD of the red maple biofilms was 1.8 times that at Gwynns Falls compared to the Patapsco tributary, which was a significant difference $\left(t_{\mathrm{df}}=14.8=-3.027, P=0.0086\right.$; Fig. 2$)$. As leaf substrate, conditioning time, and BOD measurement were consistent between the two sites, differences in respiration can be attributed to the stream water and/or the biofilm microorganisms.

The stream water chemistry differed between the study sites. Gwynns Falls water exhibited the TN, P(V), TOC, and conductivity typical of urban streams (Klein, 1979; Hoos et al., 2010; Qu et al., 2017). The higher nutrient concentrations at Gwynns Falls stimulate microbial activity, enhance in-stream decomposition, and may stem from upstream wastewater inputs due to leaky infrastructure (Gulis and Suberkropp, 2002; Cheever and Webster, 2014). Pascoal and Cássio (2004) recorded higher rates of breakdown, fungal biomass, and bacterial production in polluted urban river sites compared to forested upstream sites.

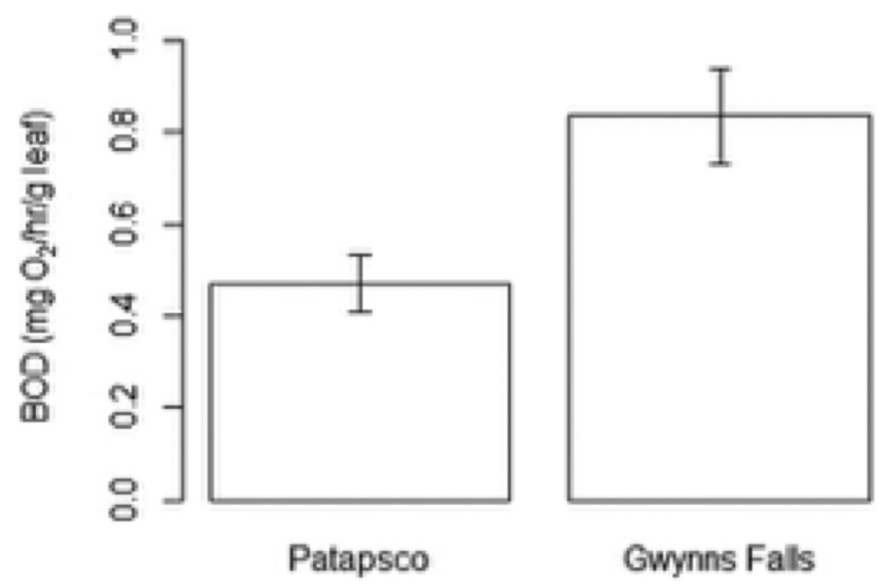

Fig. 2. Comparison of BOD at Gwynns Falls and Patapsco sites. Error bars are \pm 1 standard error of the mean. 


\section{Table 6}

Analysis of variance (ANOVA) tables for the simplest model of (A) all data, (B) Patapsco, and $(C)$ Gwynns Falls. Non-significant interactions $(P>0.05)$ are excluded. Acronyms: $\mathrm{DF}$, degrees of freedom; SS, sum of squares; MS, mean squares.

\begin{tabular}{lccccc}
\hline Effect & DF & SS & MS & F & P-value \\
\hline A. All Data & & & & & \\
Site & 1 & 0.38 & 0.38 & 11.29 & 0.0011 \\
Drug & 3 & 0.44 & 0.15 & 4.32 & 0.0064 \\
Leaf & 4 & 0.49 & 0.12 & 3.60 & 0.0086 \\
Site $\times$ Leaf & 1 & 0.20 & 0.20 & 5.79 & 0.018 \\
B. Patapsco & & & & & \\
Effect & DF & SS & MS & F & P-value \\
Drug & 3 & 0.60 & 0.20 & 4.43 & 0.0066 \\
Leaf & 3 & 0.46 & 0.15 & 3.42 & 0.022 \\
C. Gwynns Falls & & & & & \\
Effect & DF & SS & MS & F & P-value \\
Drug & 3 & 0.012 & 0.0040 & 0.30 & 0.83 \\
Leaf & 2 & 0.23 & 0.11 & 8.88 & 0.00061 \\
\hline
\end{tabular}

Similarly, faster breakdown of tulip poplar leaves occurred at Gwynns Falls as only petioles and leaf venation were recovered from the litter bags; however, all tulip poplar leaves were recovered from the litter bags at the Patapsco site, indicating slower decomposition rates.

The Gwynns Falls has a history of wastewater leaking into waterways through sewage overflows and infiltration of stormwater (Brinckerhoff, 2013; Blue Water Baltimore, 2018); therefore, the lack of ciprofloxacin and climbazole detections for the five samples analyzed in this study are not necessarily representative of cumulative antimicrobial exposures at this site. Rather, the lack of detections may stem from the use of a low number of grab samples. He et al. (2017) previously detected various antibiotics, including ciprofloxacin, erythromycin, and sulfamethoxazole, at Gwynns Run and Carrol Park, which is just downstream of the study area; furthermore, climbazole was measured at a maximum concentration of $49 \mathrm{ng} / \mathrm{L}$. Furthermore, Rosi et al. (2018) identified ciprofloxacin-resistant bacteria in the most polluted streams of the Gwynns Falls watershed, with moderate resistance identified at Carroll Park. Biofilms are not expected to be naturally resistant to synthetic fluoroquinolones, so the presence of ciprofloxacin-resistant bacteria signals a change in the microbial assemblages in Gwynns Falls streams. Other studies have likewise documented altered microbial communities in urban streams, such as an increase in humanassociated taxa, a reduction of microbial functional diversity, and reduced interaction across taxa (Hosen et al., 2017; Qu et al., 2017). Overall, the differences in microbial communities between the study sites, along with dissimilar stream water chemistry, may have contributed to the increased BOD at Gwynns Falls.

\subsection{Antimicrobial exposure microcosm study}

\subsubsection{Response of biological oxygen demand to antimicrobial treatments}

In contrast to the stream-based measurements (Fig. 2), the microcosm study showed that the BOD of Patapsco biofilms was significantly greater than that of Gwynns Falls biofilms (Table 6A). The more active microbes in Gwynns Falls microcosms may have depleted nutrients (though not measured over time here) more rapidly than microbial communities in the Patapsco microcosms. As a result, microbial activities may have slowed when the nutrient-rich stream water was not replenished, thereby, affecting the measured BOD levels. This nutrient exhaustion phenomenon has been observed in previous microcosm studies (Connell et al., 1999; Rier and Stevenson, 2006).

The BOD did not vary for the different drug treatments at Gwynns Falls (Table 6C; Fig. 3B), but a significant effect of the antimicrobials was observed in the Patapsco mesocosms (Table 6B; Fig. 3A), in which biofilms that were exposed to $10 \mu \mathrm{g} / \mathrm{L}$ ciprofloxacin respired significantly less (P adj. $=0.0045$; adjusted $P$-value from Tukey's HSD) than microbes exposed to $10 \mu \mathrm{g} / \mathrm{L}$ ciprofloxacin and $10 \mu \mathrm{g} / \mathrm{L}$ climbazole.

The lack of a difference in BOD among antimicrobial treatments in Gwynns Falls microcosms may be partially linked to the $10 \mu \mathrm{g} / \mathrm{L}$ antimicrobial dosages. This concentration was used to characterize concentrations representative of raw wastewater that may occur during a wastewater spill, during which ciprofloxacin, for example, has been measured at 3.28-69.5 $\mu \mathrm{g} / \mathrm{L}$ (Kümmerer, 2001; Radjenović et al., 2009; Kulkarni et al., 2017). Environmentally-relevant concentrations of ciprofloxacin and climbazole in surface waters are, however, much lower, at 0.010-0.045 $\mu \mathrm{g} / \mathrm{L}$ (Kolpin and Meyer, 2002; Maul et al., 2006; Deo and Haden, 2013; Rosi-Marshall et al., 2013; He et al., 2015) and 0.0084-0.530 $\mu \mathrm{g} / \mathrm{L}$ (Richter et al., 2013; Chen and Ying, 2015), respectively. Ciprofloxacin inhibits the growth of $E$. coli monocultures at $1-10 \mu \mathrm{g} / \mathrm{L}$ (He et al., 2015), and the $10 \%$ effective concentration $\left(\mathrm{EC}_{10}\right)$ for climbazole on the growth rate of diatoms and green algae is approximately $108 \mu \mathrm{g} / \mathrm{L}$ (Richter et al., 2013). These literature values, in combination with the findings of this study, indicate that $10 \mu \mathrm{g} / \mathrm{L}$ of ciprofloxacin and climbazole does not significantly affect the ability of the heterogeneous biofilm communities to process carbon. This conclusion raises important implications for future work, such as how different concentrations induce similar or dissimilar activity patterns by microbes, aimed at elucidating effects of pharmaceuticals on ecosystems.

The 14-day duration of the microcosm experiments may have also affected the conclusions of this study with respect to previous reports of drug exposure on stream biota. For example, previous studies included longer incubation periods: 34-day exposure of sediment bacteria to the triclosan antimicrobial (Drury et al., 2013); 42-day of exposure of stream fungi and bacteria to the tebuconazole fungicide (Artigas et al., 2012); and, 56-day exposure of algae and macroinvertebrates to
A

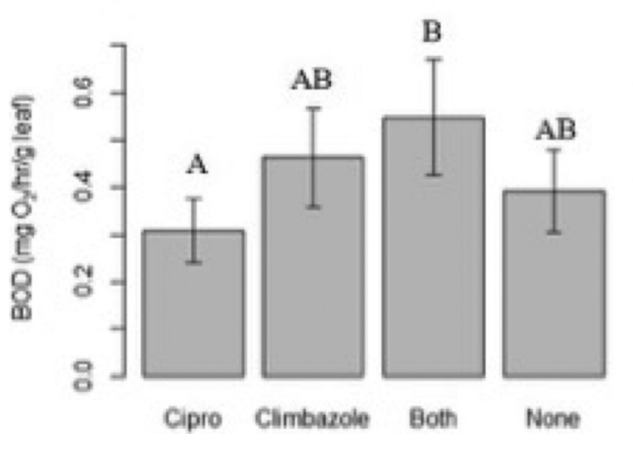

B

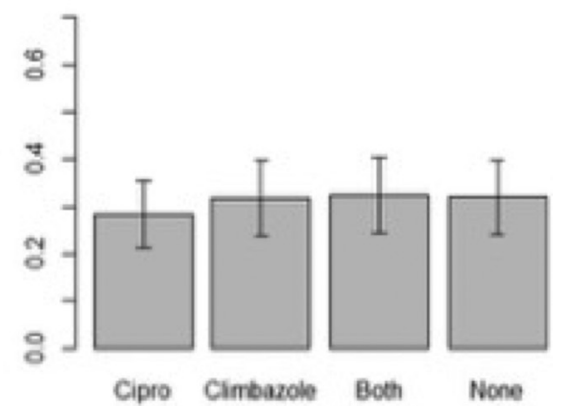

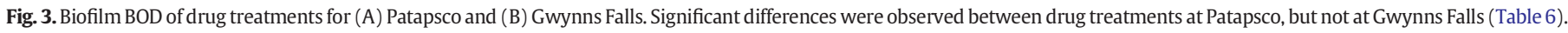

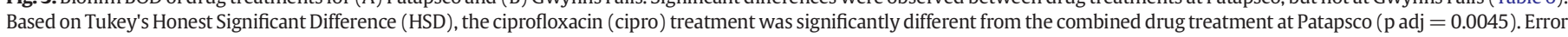
bars are \pm 1 standard error of the mean. Bars with the same letter are not significantly different. 
triclosan (Nietch et al., 2013). Fourteen days of exposure was chosen for this work to model a short-term sewage spill rather than the long-term exposure associated with the release of WWTP effluent, for example.

Although the antimicrobial concentrations were apparently too low and the exposure time too short to impact the overall decomposition rate of stream biofilms, regular contact of stream-based microorganisms with antimicrobials and other pharmaceuticals/personal care products, including UV-filters, hormones, acetaminophen, morphine, carbamazepine, and diphenhydramine (Lee et al., 2016; He et al., 2017), may have also played a role in the lack of significant differences between the treated samples and the negative controls. Exposure to low levels of chemical cocktails causes shifts in microbial community activity (Greer et al., 2012; Yergeau et al., 2012), and suggesting they can become tolerant of other compounds (Daughton and Ternes, 1999; Bonnet et al., 2016; Ancona et al., 2017; Rosi et al., 2018). At the Patapsco tributary, possible septic tank leakage may have caused microbes to become slightly tolerant towards antimicrobials, although not to the same extent as in Gwynns Falls, which is regularly exposed to wastewater as described above. This finding is supported by the significant differences that occurred in Patapsco but not Gwynns Falls microcosms, as well as the more pronounced variability of BOD among leaf treatments.

Interestingly, Patapsco biofilms exposed to $10 \mu \mathrm{g} / \mathrm{L}$ ciprofloxacin respired significantly less than microbes exposed to $10 \mu \mathrm{g} / \mathrm{L}$ of the combined drug treatment. This finding may be attributed to the complex nature of antimicrobial mixtures. In wastewater-impacted streams, antimicrobials exist as mixtures and drug-drug interactions are difficult to predict due to differing modes of action (Feron and Groten, 2002; RosiMarshall and Royer, 2012). Interactions can be antagonistic (i.e., weaker response than the sum of individual responses) or synergistic (i.e., stronger response than the sum of individual responses) (Groten et al., 2001). The relative concentrations of antimicrobials in mixtures also factors into drug interactions (Groten et al., 2001). For instance, an interaction can be synergistic at one dose but antagonistic at another (Pomati et al., 2008). As BOD increased in the Patapsco mesocosms when both ciprofloxacin and climbazole were present compared to the ciprofloxacin only scenario, an antagonistic interaction may have reduced the capacity of
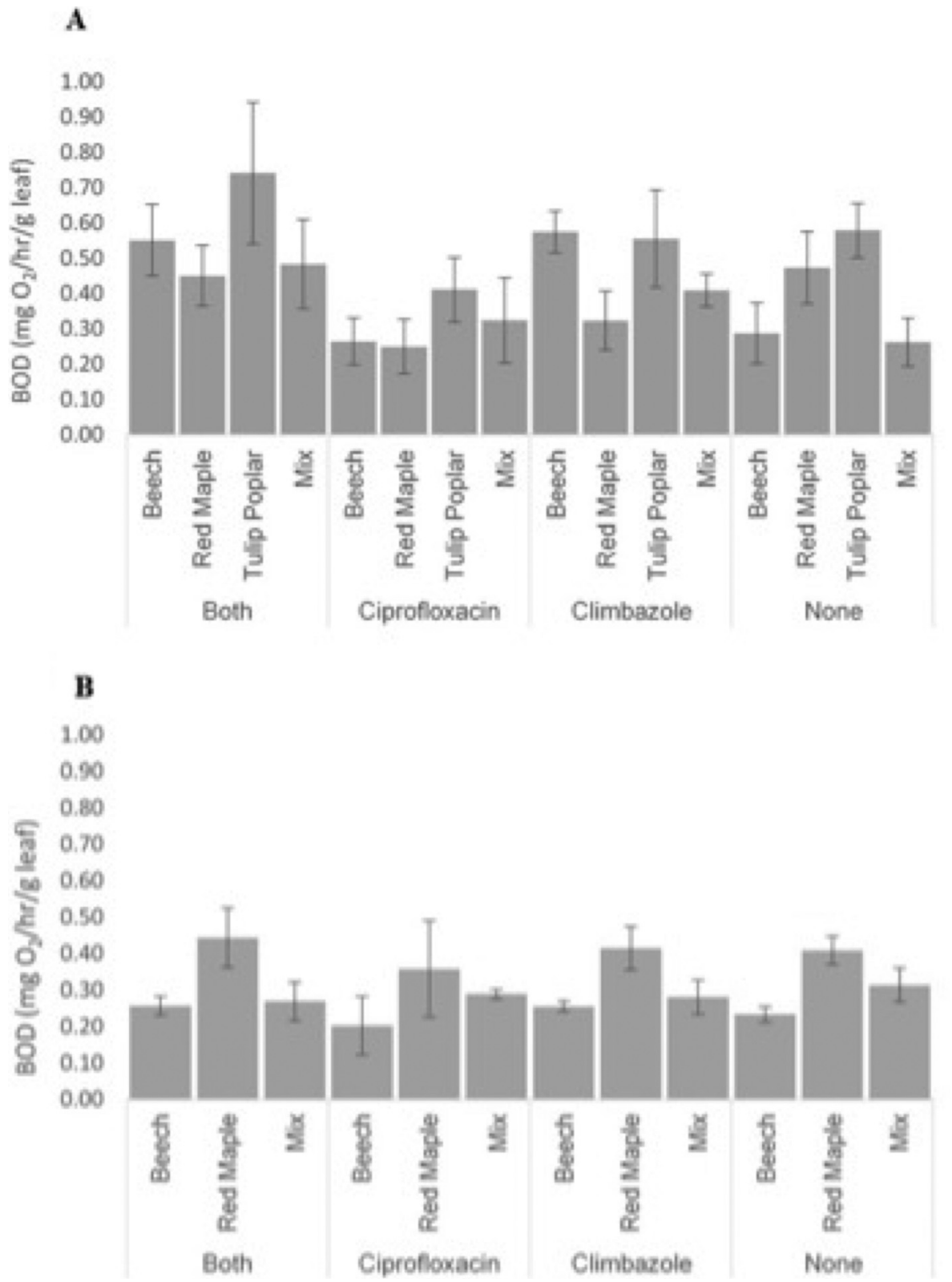

Fig. 4. Average BOD measurements by antimicrobial and leaf treatment for (A) Patapsco and (B) Gwynns Falls. Error bars are \pm 1 SE. 
both compounds to act upon bacteria and fungi. Since a significant difference in BOD was not observed between the antimicrobial mixture and climbazole experiments, ciprofloxacin may have exerted a stronger impact on the microbial communities than climbazole.

The higher respiration in the Patapsco biofilms exposed to both antimicrobials compared to ciprofloxacin alone may indicate that these compounds stimulated microbial activity, rather than suppressing carbon processing. Previous work has shown that low antimicrobial concentrations can benefit select microorganisms (e.g., stimulate growth, reproduction, and longevity) due to activation of survival or repair mechanisms (Robinson et al., 2005; Yang et al., 2008; Nietch et al., 2013; Charlebois et al., 2014; Fernández et al., 2016). This concept is called hormesis (Calabrese and Baldwin, 1998, 2002; Mattson, 2008). A hormetic response may have, therefore, contributed to the higher BOD in mesocosms containing both ciprofloxacin and climbazole by triggering additional cell activities that require more oxygen. This possible explanation of the higher respiration in Patapsco biofilms exposed to ciprofloxacin and climbazole may have other important implications in urban and suburban streams impacted by wastewater and/or wastewater effluent.

\subsubsection{Response of biological oxygen demand to leaf treatments}

Single species leaf cores that were not exposed to antimicrobials displayed the expected trend in BOD based on leaf properties and previous studies (Petersen and Cummins, 1974; Webster and Benfield, 1986; Allan and Castillo, 2007). Significant differences were identified between the leaf treatments in mesocosms for each site, although this difference was not due to an interaction between the leaf type and the antimicrobial treatments (Table 6). In Patapsco mesocosms, biofilms on tulip poplar, the most labile leaf species, had a significantly higher BOD compared to leaf mixture biofilms $(\mathrm{P}$ adj. $=0.028)$ and red maple biofilms, which are the second-most labile species ( $P$ adj. $=$ 0.034; Fig. 4A). Biofilms on the most refractory species, beech, did not have significantly different BOD values compared to tulip poplar, red maple, or the leaf mixture (P adj. > 0.05). Among Gwynns Falls mesocosms, red maple biofilms respired significantly more than those on beech leaves ( $\mathrm{P}$ adj. $=0.00054)$ and the red maple/beech mixture (P adj. = 0.016; Fig. 4B).

\subsection{Ability of leaf mixtures to buffer against antimicrobial exposure}

The BOD of leaf mixture biofilms, irrespective of drug treatment, was not statistically different from the average combined BOD of the single species litter biofilms at either the Patapsco tributary ( $P$ adj. $=0.46$ ), Gwynns Falls ( $P$ adj. $=0.95$ ), or between the sites ( $P$ adj. $=0.63$; Fig. 5). Leaf mixture microorganisms also did not demonstrate a higher BOD than the leaf species with the highest microbial BOD in a given

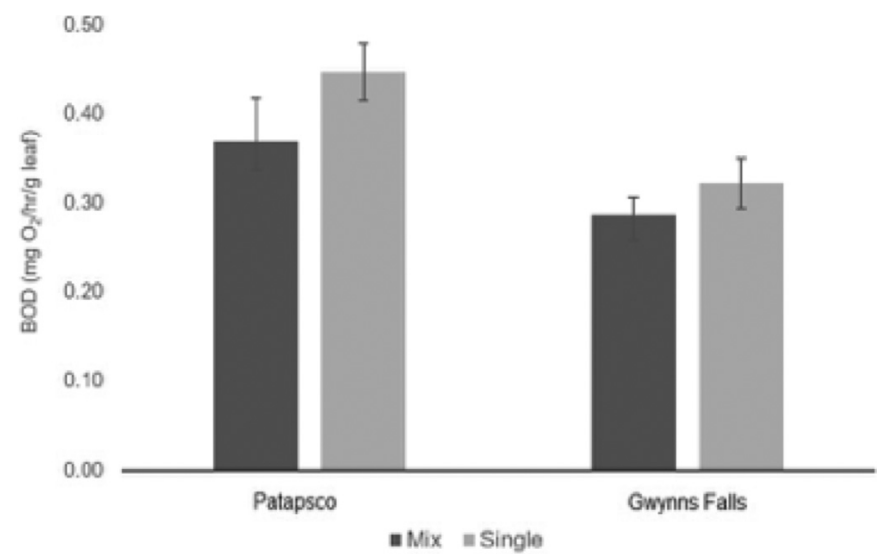

Fig. 5. Average BOD of biofilms from leaf mixtures versus the combined single-species treatments. Error bars are $\pm 1 \mathrm{SE}$. antimicrobial treatment (e.g., tulip poplar in Patapsco and red maple in Gwynns Falls), but leaf mixture biofilms did not always have the lowest BOD of the leaf treatments (Fig. 4).

A mixture of leaf species was expected to dampen the effects of antimicrobial exposure on BOD because the presence of different physical and chemical leaf compositions supports diverse assemblages of microorganisms and macroinvertebrates, providing functionally redundant traits to offset the potential inhibition of certain species due to antimicrobials (Petersen and Cummins, 1974; Webster and Benfield, 1986). For this reason, streams that are surrounded by a variety of tree species are typically more stable due to the availability of nutrients from labile and recalcitrant leaf species over an extended period of time (Swan and Palmer, 2006). In leaf mixtures, species composition plays a greater role in decomposition rates than species richness (Swan and Palmer, 2004; Chauvet et al., 2007; Kominoski et al., 2009). The importance of a single mixture over richness may explain why the study mixtures (e.g., tulip poplar/red maple/beech at Patapsco or red maple/beech at Gwynns Falls) did not result in increased microbial respiration compared to the single species experiments. Refractory species like beech can slow decomposition of a mixture to rates below that of the refractory species alone (Swan and Palmer, 2006; Stoler and Relyea, 2011; Ferreira et al., 2016; but see Sanpera-Calbet et al., 2009), but this situation was not observed in this study as the beech biofilms generally had a lower BOD than the mixtures. Overall, the leaf mixture microbes did not yield an increased BOD compared to single species leaf treatments upon antimicrobial exposure.

\section{Conclusion}

In sum, Gwynns Falls displayed characteristics of an urban stream, including elevated microbial BOD and nutrient concentrations compared to the Patapsco headwater stream. Climbazole was detected at $7.7 \pm 0.9 \mathrm{ng} / \mathrm{L}$ on one date at Patapsco, suggesting potential contamination from upstream sources (e.g., septic systems); however, no other detections for ciprofloxacin or climbazole were recorded for the water samples at Patapsco or Gwynns Falls.

Ciprofloxacin and climbazole, in combination and separately, may not affect macro-scale carbon processing of the leaf biofilms as no antimicrobial treatments resulted in BOD values that differed from the noantimicrobial controls. Additionally, leaf mixtures may not provide a buffering effect when exposed to antimicrobials despite the potential presence of more complex microbial communities compared to single species leaf litter.

These results suggest that, for the tested conditions, antimicrobials do not significantly affect the ability of microbial communities to process carbon in leaves from urban and rural streams; however, future research is needed to elucidate the concentrations and exposure times at which negative impacts to carbon cycling occur.

\section{Acknowledgements and funding}

This effort was supported with resources from the U.S. National Science Foundation Long-term Ecological Research (LTER) Program (Grant No. DEB-1027188) and Environmental Engineering Program (Grant No. CBET-1653726). Any opinions, findings, and conclusions or recommendations expressed in this material are those of the authors and do not necessarily reflect the views of the National Science Foundation.

\section{References}

Allan, J.D., Castillo, M., 2007. Stream Ecology: Structure and Function of Running Waters 2nd edition. Springer, pp. 105-196.

American Society of Civil Engineers, 2013. Report Card for America's Infrastructure. Retrieved from:. https://www.infrastructurereportcard.org/a-big-wiin-for-water-resources/\#p/drinking-water/overview.

Ancona, V., Caracciolo, B., and Grenni, P. (2017). Ecological effects of antibiotic on natura ecosystems: a review. Microchemical Journal. 136. 25-39. 
Andreozzi, R., Nicklas, P., Raffaele, M., 2003. Pharmaceuticals in STP effluents and their solar photodegradation in aquatic environment. Chemosphere. 50 (10), 1319-1330.

Artigas, J., Majerholc, J., Foulquier, A., Margoum, C., Volat, B., Neyra, M., Pesce, S., (2012). Effects of the fungicide tebuconazole of microbial capacities for litter breakdown in streams. Aquatic Toxicology. 122-123. 197-205.

Bärlocher, F. and Graça, M. (2002). Exotic riparian vegetation lowers fungal diversity but not leaf decomposition in Portuguese streams. Freshwater Biology. 47. 1123-1135.

Besemer, K., 2015. Biodiversity, community structure and function of biofilms in stream ecosystems. Res. Microbiol. 166 (10), 774-781.

Blue Water Baltimore, 2018. Water Quality in the Gwynns Falls. Blue Water Baltimore. Retrieved from:. https://www.bluewaterbaltimore.org/learn/water-quality-in-thegwynns-falls/.

Bonnet, J., Bricheux, G., Donnadieu-Bernard, F., Forestier, C., Nakusi, L., Ory, J., Togola, A. and Traore, O. (2016). Ciprofloxacin residue and antibiotic-resistant biofilm bacteria in hospital effluent. Environmental Pollution. 214. 635-645.

Brausch, J., Rand, G., 2011. A review of personal care products in the aquatic environment: environmental concentrations and toxicity. Chemosphere. 82 (11), 1518-1532.

Brinckerhoff, P. (2013). Middle Gwynns falls small watershed action plan: volume II. Department of Environmental Protection and Sustainability. 1-522.

Calabrese, E., Baldwin, L., 1998. Hormesis as a biological hypothesis. Environ. Health Perspect. 106 (February), 357-372.

Calabrese, E. and Baldwin, L. (2002). Defining hormesis. Human and Experimental Toxicology. 21. 91-97.

Charlebois, A., Jacques, M., Archambault, M., 2014. Biofilm formation of Clostridium perfringens and its exposure to low-dose antimicrobials. Front. Microbiol. 5 (183), 1-11.

Chauvet, E., Gessner, M., Lercef, A., Popsecu, C., Risnoveanu, G., 2007. Decomposition of diverse litter mixtures in streams. Ecology. 88 (1), 219-227.

Cheever, B., Webster, J., 2014. Effects of consumers and nitrogen availability on heterotrophic microbial activity during leaf decomposition in headwater streams. Freshw. Biol. 59 (8), 1768-1780.

Chen, Z. and Ying, G. (2015). Occurrence, fate and ecological risk of five typical azole fungicides as therapeutic and personal care products in the environment: a review. Environmental International. 84.142-153.

Chesapeake Bay Foundation. (2016). Water tests find high levels of fecal material in area streams and rivers, including swimming holes. [Press release].

Cleuvers, M. (2004). Mixture toxicity of the anti-inflammatory drugs diclofenac, ibuprofen, naproxen, and acetylsalicylic acid. Ecotoxicology and Environmental Safety. 59. 309-315.

Connell, D., Lam, P., Richardson, B., Wu, R., 1999. Introduction to Ecotoxicology. Publishing, Blackwell, p. 97

Daughton, C., Ternes, T., 1999. Pharmaceuticals and personal care products in the environment: agents of subtle change? Environ. Health Perspect. 107 (6), 907-938.

Deo, R., Haden, R., 2013. Pharmaceuticals in the built and natural water environment of the United States. Water. 5 (3), 1346-1365.

Drury, B., Scott, J., Rosi-Marshall, E., Kelly, J., 2013. Triclosan exposure increases triclosan resistance and influences taxonomic composition of benthic bacterial communities. Environ. Sci. Technol 47 (15), 8923-8930.

Dussault, E., Balakrishnan, V., Sverko, E., Solomon, K., Sibley, P., 2008. Toxicity of human pharmaceuticals and personal care products to benthic invertebrates. Environ. Toxicol. Chem. 27 (2), 425-432.

Ebele, A., Abou-Elwafa Abdallah, M., Harrad, S., 2017. Pharmaceuticals and personal care products (PPCPs) in the freshwater aquatic environment. Emerging Contaminants 3 (1), 1-16.

Erickson, A., Weiss, P., Gulliver, J., 2013. Optimizing Stormwater treatment practices: a handbook of assessment and maintenance. Springer Science and Business Media. New York 11-22.

Feckler, A., Kahlert, M., Bundschuh, M., 2015. Impacts of contaminants on the ecologica role of lotic biofilms. Bull. Environ. Contam. Toxicol. 95 (4), 421-427.

Fernández, D., Tummala, M., Schreiner, V., Duarte, S., Pascoal, C., Winkelman, C., Mewes, D., Muñoz, K., and Schäfer, R. (2016). Does nutrient enrichment compensate fungicide effects on litter decomposition and decomposer communities in streams? Aquatic Toxicology. 174. 169-178.

Feron, V., Groten, J., 2002. Toxicological evaluation of chemical mixtures. Food Chem. Toxicol. 40 (6), 825-839.

Ferreira, V., Koricheva, J., Pozo, J., Graça, M. (2016). A meta-analysis on the effects of changes in the composition of native forests on litter decomposition in streams. For est Ecology and Management. 364. 27-38.

Gessner, M., Chauvet, E., Dobson, M., 1999. A perspective on leaf litter breakdown in streams. Oikos 85 (2), 377-384.

Greer, C., Lawrence, J., Sanschagrin, S., Waiser, M., Yergeau, E., 2012. Sub-inhibitory concentrations of different pharmaceutical products affect the meta-transcriptome of river biofilm communities cultivated in rotating annular reactors. Environ. Microbiol. Rep. 4 (3), 350-359.

Groten, J., Feron, V., Sühnel, J., 2001. Toxicology of simple and complex mixtures. Trends Pharmacol. Sci. 22 (6), 316-322.

Gulis, V., Suberkropp, K., 2002. Leaf litter decomposition and microbial activity in nutrient-enriched and unaltered reaches of a headwater stream. Freshw. Biol. 48 (1), 123-134

Gulis, V. and Suberkropp, K. (2003). Leaf litter decomposition and microbial activity in nutrient-enriched and unaltered reaches of a headwater stream. Freshwater Biology. 48. 123-134.

Hach, C., Klein, R., and Gibbs, C. (1997). Introduction to biochemical oxygen demand. Technical Information Series. 7. 1-22.

Harrison, M., Stanwyck, E., Beckingham, B., Hanlon, B., Newcomer, J., 2012. Smart growth and the septic tank: wastewater treatment and growth management in the Baltimore region. Land Use Policy 29 (3), 483-492.
He, K., and Blaney, L. (2015). Systematic optimization of an SPE with HPLC-FLD method for fluoroquinolone detection in wastewater. Journal of Hazardous Materials. 282. 96-105.

He, K., Soares, A., Adejumo, H., McDiarmid, M., Squibb, K., and Blaney, L. (2015). Detection of a wide variety of human and veterinary fluoroquinolone antibiotics in municipal wastewater and wastewater-impacted surface water. Journal of Pharmaceutical and Biomedical Analysis. 106. 136-143.

He, K., Hain, E., Blaney, L., 2017. Seasonal analysis of contaminants of emerging concern in the Gwynns falls watershed. Presentation, Baltimore Ecosystem Study Annual Meeting (Baltimore, MD) (October 26, 2017).

Hoos, A., Robinson, J., Aycock, R., Knight, R., and Woodside, M. (2010). Sources, instream transport, and trends of the nitrogen, phosphorus, and sediment in the lower Tennessee River basin, 1980-96. U.S. Geological Survey Water-Resources Investigations Report. 99-4139.

Hosen, J., Febria, C., Crump, B., Palmer, M. (2017). Watershed urbanization linked to differences in stream bacterial community composition. Frontiers in Microbiology. 8. $1-17$

Hwang, S., Hwang, S., Park, S., Lee, S., 2016. Examining the relationships between watershed urban land use and stream water quality using linear and generalized additive models. Water. 8 (4), 2-15.

Hyer, K., 2006. A multiple-tracer approach for identifying sewage sources to an urban stream system. Scientific Investigations Report 2006-5317.

Klein, R., 1979. Urbanization and stream quality impairment. J. Am. Water Resour. Assoc. 15 (4), 948-963.

Kolpin, D. and Meyer, M. (2002). Pharmaceuticals, Hormones, and Other Organic Wastewater Contaminants in U. S. Streams, 1999-2000: A National Reconnaissance. Environ. Sci. Technol. 36(6). 1202-1211.

Kominoski, J., Hoellein, T., Kelly, J., Pringle, C., 2009. Does mixing litter of different qualities alter stream microbial diversity and functioning on individual litter species? Oikos. 118 (3), 457-463.

Kulkarni, P., Olson, N., Raspanti, G., Goldstein, R., Gibbs, S., Sapkota, A., Sapkota, A., 2017. Antibiotic concentrations decrease during wastewater treatment but persist at low levels in reclaimed water. Int. J. Environ. Res. Public Health 14 (6), 1-13.

Kümmerer, K., 2001. Drugs in the environment: emission of drugs, diagnostic aids and disinfectants into wastewater by hospitals in relation to other sources-a review. Chemosphere. 45 (6-7), 957-969.

Kümmerer, K., 2003. Significance of antibiotics in the environment. J. Antimicrob. Chemother. 52 (1), 5-7.

Lawrence, J.R., Zhu, B., Swerhone, G.D.W., Roy, J., Tumber, V., Waiser, M. J., Topp, E. and Korber, D.R. (2012). Molecular and microscopic assessment of the effects of caffeine, acetaminophen, diclofenac and their mixtures on river biofilm communities. Environmental Toxicology and Chemistry. 31. 508-517.

Lee, S., Kelly, J., Paspalof, A., Richmond, E., Rosi-Marshall, E., Snow, D., 2016. Occurrence and potential biological effects of amphetamine on stream communities. Environ. Sci. Technol. 50 (17), 9727-9735.

Mattson, M., 2008. Hormesis defined. Ageing Res. Rev. 7 (1), 1-7.

Maul, J., Schuler, L., Belden, J., Whiles, M., Lydy, M., 2006. Effects of the antibiotic ciprofloxacin on stream microbial communities and detritivorous macroinvertebrates. Environmental toxicology and chemistry / SETAC. 25 (6), 1598-1606.

Mehring, A., Lowrance, R., Vellidis, G., Helton, A., Pringle, C., Bosch, D., 2010. Effects of Leaf Litter Decay and Forest Composition on Blackwater River Benthic Oxygen Demand. Vellidis Research Group at the University of Georgia.

Melillo, J., Aber, J., Muratore, J., 1982. Nitrogen and lignin control of hardwood leaf litter decomposition dynamics. Ecology. 63 (3), 15-28.

Meter, R., Swan, C., Trossen, C., 2012. Effects of road deicer ( $\mathrm{NaCl}$ ) and amphibian grazers on detritus processing in pond mesocosms. Environ. Toxicol. Chem. 31 (10), 2306-2310.

Monteiro, S., Boxall, A., 2010. Occurrence and fate of human pharmaceuticals in the environment. Reviews of Environmental Contamination and. Toxicology. 202, 53-154.

Morgan, R., Kline, K., Kline, M., Cushman, S., Sell, M., Weitzell, R., Churchill, J., 2012. Stream conductivity: relationships to land use, chloride, and fishes in Maryland streams. N. Am. J. Fish Manag. 32 (5), 941-952.

Newman, M., Liles, M., Feminella, J., 2015. Litter breakdown and microbial succession on two submerged leaf species in a small forested stream. PLoS One 10 (6).

Nietch, C., Quinlan, E., Lazorchak, J., Impellitteri, C., Raikow, D., Walters, D., 2013. Effects of a chronic lower range of triclosan exposure on a stream mesocosm community. Environ. Toxicol. Chem. 32 (12), 2874-2887.

Ostrofsky, M., 1993. Effect of tannins on leaf processing and conditioning rates in aquatic ecosystems: an empirical approach. Canadian Journal of Fisheries and Aquatic. Science. $50,1176-1180$

Parkin T., Doran, J., and Franco-Vizcaíno, E. (1996). Field and laboratory tests of soil respiration. Methods for assessing soil quality. Madison, WI. 231-45.

Pascoal, C., Cássio, F., 2004. Contribution of fungi and bacteria to leaf litter decomposition in a polluted river. Appl. Environ. Microbiol. 70 (9), 5266-5273.

Peters, K., Bundschuh, M., Schäfer, R. B. (2013). Review on the effects of toxicants on freshwater ecosystem functions. Environmental Pollution. 180. 324-329.

Petersen, R. and Cummins, K. (1974). Leaf processing in a woodland stream. Freshwater Biology. 4. 343-368.

Petrie, B., Barden, R., and Kasprzyk-Horden, B. (2015). A review on emerging contaminants in wastewaters and the environment: current knowledge, understudied areas and recommendations for future monitoring. Water Research. 72. 3-27.

Pomati, F., Orlandi, C., Clerici, M., Luciani, F., Zuccato, E., 2008. Effects and interactions in an environmentally relevant mixture of pharmaceuticals. Toxicol. Sci. 102 (1), 129-137.

Qu, X., Ren, Z., Zhang, M., Xhang, Y., Liu, X., Peng, W., 2017. Influences of anthropogenic and use on microbial community structure and functional potentials of stream benthic biofilms. Sci. Rep. 7 (1), 1-12. 
Radjenović, J., Petrović, M., Barceló, D., 2009. Fate and distribution of pharmaceuticals in wastewater and sewage sludge of the conventional activated sludge (CAS) and advanced membrane bioreactor (MBR) treatment. Water Res. 43 (3), 831-841.

Richter, E., Wick, A., Ternes, T., Coors, A., 2013. Ecotoxicity of climbazole, a fungicide contained in antidandruff shampoo. Environ. Toxicol. Chem. 32 (12), 2816-2825.

Rier, S., Stevenson, J., 2006. Response of periphytic algae to gradients in nitrogen and phosphorus in streamside mesocosms. Hydrobiologia. 561 (1), 131-147.

Robinson, A., Belden, A., Lydy, M., 2005. Toxicity of fluoroquinolone antibiotics to aquatic organisms. Environ. Toxicol. Chem. 24 (2), 423-430.

Rosi, E.J., Bechtold, H.A., Snow, D., Rojas, M., Reisinger, A.J., Kelly, J.J., 2018. Urban stream microbial communities show resistance to pharmaceutical exposure. Ecosphere. 9 (1), 1-16.

Rosi-Marshall, E., Kincaid, D., Bechtold, H., Royer, T., Rojas, M., Kelly, J., 2013. Pharmaceuticals suppress algal growth and microbial respiration and alter bacterial communities in stream biofilms. Ecol. Appl. 23 (3), 583-593.

Rosi-Marshall, E., Kelly, J., 2015. Antibiotic stewardship should consider environmental fate of antibiotics. Environ. Sci. Technol. 49 (9), 5257-5258.

Rosi-Marshall, E., Royer, T., 2012. Pharmaceutical compounds and ecosystem function: an emerging research challenge for aquatic ecologists. Ecosystems. 15 (6), 867-880.

Royer, T. and Minshall, W. (2001). Effects of nutrient enrichment and leaf quality on the breakdown of leaves in a hardwater stream. Freshwater Biology. 46. 603-610.

Sanpera-Calbet, I., Lercef, A., Chauvet, E., 2009. Leaf diversity influences in-stream litter decomposition through effects on shredders. Freshw. Biol. 54 (8), 1671-1682.

Stelzer, R., Heffernan, J., and Likens, G. (2003). The influence of dissolved nutrients and particulate organic matter quality on microbial respiration and biomass in a forest stream. Freshwater Biology. 48. 1925-1937.
Stoler, A., Relyea, R., 2011. Living in the litter: the influence of tree leaf litter on wetland communities. Oikos. 120 (6), 862-872.

Swan, C., Palmer, M., 2004. Leaf diversity alters litter breakdown in a Piedmont stream. J. N. Am. Benthol. Soc. 23 (10), 15-28.

Swan, C., Palmer, M., 2006. Composition of speciose leaf litter alters stream detritivore growth, feeding activity and leaf breakdown. Oecologia. 147 (3), 469-478.

Tank, L., Webster, J., Benfield, E., 1993. Microbial respiration on decaying leaves and sticks in a southern Appalachian stream. Journal of North American Benthological Society. 12 (4), 394-405

United States Environmental Protection Agency. (2002). The clean water and drinking water infrastructure gap analysis. Retrieved from: https://www.epa.gov/sites/production/files/2015-03/documents/2013_dqrs_certified.pdf

Webster, J.R., and Benfield, E.F. (1986). Vascular plant breakdown in freshwater ecosystems. Annual Review of Ecology and Systematics. 17. 567-594.

Yang, L., Ying, G., Su, H., Stauber, J., Adams, M., Binet, M., 2008. Growth-inhibiting effects of 12 antibacterial agents and their mixtures on the freshwater microalgae Pseudokirchneriella subcapitata. Environ. Toxicol. Chem. 27 (5), 1201-1212.

Yergeau, E., Sanschagrin, S., Waiser, M., Lawrence, J., Greer, C., 2012. Sub-inhibitory concentrations of different pharmaceutical products affect the meta-transcriptome of river biofilm communities cultivated in rotating annular reactors. Environ. Microbiol. Rep. 4 (3), 350-359. 